\title{
ЦЕНТРАЛЬНЫЙ ГОСУДАРСТВЕННЫЙ АРХИВ ЧУВАШСКОЙ РЕСПУБЛИКИ: ОСНОВНЫЕ НАПРАВЛЕНИЯ ДЕЯТЕЛЬНОСТИ В 1991-2004 ГГ.
}

\section{THE CENTRAL STATE ARCHIVE OF THE CHUVASH REPUBLIC: MAIN DIRECTIONS OF ACTIVITY IN 1991-2004}

\section{A. Kuznetsov}

Summary: Analysis of main directions of activity of the largest archive in Chuvashia Republic The central state archive of the Chuvash Republic in 1991-2004. Problems and achievements of archivists in the field of preservation of archival documents, archiving, creation of scientific reference apparatus, accounting and use of archival materials have been noted. Attention is paid to archive management and staffing.

Keywords: archival fund, archiving, state archives, archive, information resource, Chuvash Republic.
Д окументы Архивного фонда Российской Федерации отражают правовые и организационные основы становления и развития государства, соренитета страны, ее внешнеполитической деятельности, эффективного функционирования всех структур, развития науки, техники и культуры. В 1990-е гг. в силу построения нового демократического государства и необходимости формирования иной идеологии внимание к архивной сфере как никогда усилилось, коренным образом были пересмотрены вопросы доступа и ведомственной принадлежности документов. С другой стороны, архивная отрасль наиболее болезненно испытывала на себе финансовые трудности того периода, безопасность информационных ресурсов была поставлена под угрозу.

Долгое время единственным республиканским государственным архивом, подведомственным непосредственно органу управления архивным делом, оставался Центральный государственный архив Чувашской АССР (далее - ЦГА ЧР), образованный еще постановлением СНК Чувашской АССР от 14 июня 1941 г [7, с. 58].

Если в 1991 г. структура ЦГА ЧР включала в себя восемь отделов и три сектора (при общей штатной численности 71 человек), то в 2004 г. - шесть отделов (46 человек). Заметное уменьшение численности архивных работников произошло во исполнение Указа Президента Чувашской Республики от 01 июня 1998 г. № 69 «О чрезвычайных ме-

\author{
Кузнецов Антон Константинович \\ к.и.н., доцент, ФГБОУ ВО «Чувашский государственный \\ университет имени И.Н. Ульянова» (2. Чебоксары), \\ kuznetsov-ak@mail.ru
}

Аннотация: Представлен анализ основных направлений деятельности крупнейшего архивного учреждения Чувашии Центрального государственного архива Чувашской Республики в 1991-2004 гг. Отмечены проблемы и достижения архивистов в сфере обеспечения сохранности архивных документов, комплектования архива, создания научно-справочного аппарата, учета и использования архивных материалов. Уделено внимание вопросам управления архивом и кадрового обеспечения.

Ключевые слова: архивный фонд, архивное дело, государственный архив, архив, информационный ресурс, Чувашская Республика.

рах по финансово-экономическому оздоровлению организаций и усилению бюджетно-налоговой дисциплины». Штатная численность ЦГА ЧР составила 55,9\% от количества сотрудников 1992 г [1, д. 769, л. 1].

В 2004 году архив получил новое название - РГУ «Государственный исторический архив Чувашской Республики» Минкультуры Чувашии, по-прежнему оставшись крупнейшим архивным учреждением республики.

Состав источников комплектования госархива в рассматриваемые годы по существу не совершенствовался, а формировался заново. На 01 января 1991 г. в списке источников комплектования ЦГА ЧР числилось 265 ведомственных архивов, в т.ч. три объединенных (Министерства сельского хозяйства Чувашской АССР, Министерства торговли Чувашской АССР и Чувашоблсовпрофа) [2, д. 992, л.32]. В 1997 г. было принято решение о создании единого архивного учреждения по работе с организациями и предприятиями - Чувашской республиканской службы формирования Архивного фонда, ведомственных архивов и делопроизводства.

Основные хранилища архивных документов располагались по адресу: г. Чебоксары, пр. Ленина, д. 16 Б. Здание было построено в 1963 г. с общей площадью 3048 кв. м., оснащено системами водо- и электрооборудования, калориферной системой, системой отопления архивохранилищ и охранно-пожарной сигнализацией. 
В 1991-1993 гг. был проведен текущий ремонт, осуществлена реконструкция хранилища (установлены двухъярусные металлические стеллажи), в 1995-2000 гг. произведен ремонт кровли архива [2, д. 824, л. 83].

Практически на протяжении всего рассматриваемого периода главной проблемой в сфере обеспечения сохранности документов оставалась нехватка площадей. С 2000 г. ЦГА ЧР, одно из главных хранилищ документов в республике, был вынужден приостановить плановое комплектование управленческой документацией. Прием документов от учреждений-источников комплектования осуществлялся в исключительных случаях (от ликвидированных организаций, не имевших правопреемников) [5, с. 26].

В полной мере здание архива не отвечало требованиям обеспечения сохранности документов. Отсутствовали помещения для приема, акклиматизации и временного хранения поступавших в архив документов, изолированного хранения особо ценных документов. В силу нехватки площадей в читальный зал так и не были переданы третьи экземпляры описей, что в условиях расширения использования документов неоправданно увеличивало нагрузку на работников архивохранилищ.

Для сохранности документов немаловажную роль играли оптимальные для документов температурновлажностный и санитарно-гигиенический режимы. Температура и влажность в хранилищах контролировалась с помощью психрометров. Санитарно-гигиенические условия поддерживались проведением регулярной влажной уборки, ежемесячных санитарных дней. Несмотря на наличие приборов, сотрудники ЦГА ЧР не смогли обеспечить выполнения нормативов температурно-влажностного режима хранения документов (из-за сильной изношенности калориферной системы). Так, в 1998 г. в госархиве было зафиксировано наличие плесени в хранилище дореволюционных фондов. Биоповреждения обнаружены по документам информационного насыщенного фонда № 193 «Управление Алатырского удельного округа» $[1$, д. 920, л. 18]. В связи с отсутствием дезокамеры и изолированного помещения дезинфекция проводилась только в летний период.

В соответствии с плановыми показателями проводилось обеспыливание и картонирование дел. В период с 1991-1996 гг. в ЦГА ЧР проведено картонирование по фондам I и II категории в объеме 28578 ед. хр [1, д. 920, л. 15]. В дальнейшем из-за отсутствия финансовых средств оно было приостановлено. Имела место также запыленность документов, ${ }^{2} / 3$ которых не были закартонированы.

За рассматриваемый период не удалось избежать аварийных ситуаций. В апреле 2000 г. из-за прорыва водопровода, находившегося рядом со зданием ЦГА ЧР, произошло подтопление архивохранилища, в котором хранился фонд кинофотодокументов и страховой фонд микрофильмов, подмокли также дела по личному составу. Благодаря своевременно принятым мерам документы, за исключением двух частей негатива кинофотодокументов, удалось спасти [1, д. 920, л. 16].

Целенаправленно стало осуществляться в 1991-2004 гг. еще одно направление обеспечения сохранности документов - работа с особо ценными документами. На основании приказа директора ЦГА ЧР от 08 января 1992 г. № 2 «Об организации работы с особо ценными документами» в госархиве была создана специальная комиссия.

В фондах Алатырской, Свияжской провинциальных канцелярий, Курмышской воеводской канцелярии все дела в количестве 36 ед. хр. были отнесены к особо ценным. В них содержатся интересные документы, характеризующие развитие экономики, социально-экономическое положение крестьян за 1729-1779 гг., имеются полиграфические особенности. Выявлены особо ценные документы и по фондам советского периода: Областной продовольственный комиссариат, Коммунальный и Переселенческий отделы, Чувашское отделение языка и культуры Восточного пединститута [1, д. 920, л. 26].

Таким образом, за 1991-2004 гг. выявление особо ценных документов на бумажной основе было организовано по фондам I и II категории. Всего было выявлено и описано 6424 ед. хр. на бумажной основе и 1143 ед. фотодокументов. На 01 января 2005 г. в ЦГА чР количественный показатель выявленных особо ценных ед. хр. составлял 24321 ед. хр. на бумажной основе и 3797 ед. фотодокументов [1, д. 992, л. 31].

ЦГА ЧР проводил целенаправленную работу по проверке физического состояния таких документов. Так, в 1994 г. выявлялись документы с затухающим текстом по фондам Алатырского Киево-Николаевского Новодевичьего монастыря и коллекции рукописей XVII в. Заведены карточки учета документов с затухающим текстом на 42 ед. хр. Однако в связи с отсутствием специального оборудования и средств работа по восстановлению таких документов в рассматриваемый период не проводилась [8, с. 147].

Отделом микрофильмирования, фотокопирования и реставрации документов госархива в эти годы была проведена огромная и очень важная работа по созданию страхового фонда особо ценных документов. Всего за 1991-2005 гг. было изготовлено 740115 кадров. В течение 1991-1994 гг. - по 120 тысяч кадров ежегодно. В этом немалая заслуга принадлежит оператору Л.А. Данилову, 
который более 40 лет посвятил созданию страхового фонда [3, с. 50].

В последующие годы эти показатели стали заметно снижаться (в 1995 г. - 80085 кадров, 1996 г. - 60264, 1998 г. - 45453) [2, д. 992, л. 27]. C IV квартала 1999 г. из-за отсутствия средств на приобретение негативной пленки страховой фонд не создавался. Существовали и другие проблемы: сокращение штатной численности отдела, отвлечение сотрудников на другие виды работ, износ оборудования, отсутствие монтажного стола, вытяжной вентиляции, запыленность дел, отсутствие площадей и т.д [2, д. 819, л. 27-28].

С 2003 г. ЦГА ЧР приступил к созданию страхового фонда на фотодокументы в цифровом формате, было отсканировано 1025 фотодокументов [2, д. 1064, л. 40]. Однако методически работа в данном направлении не была обеспечена.

С 1965 г. начал формироваться фонд пользования ЦГА ЧР, но затем вплоть до 1988 г. эта работа была прекращена. В 1993 г. фонд пользования был приведен в рабочее состояние и был передан в количестве 5353 единиц из архивохранилища кинофотофонодокументов в архивохранилище для выдачи в читальный зал. Таким образом, исследователям с этого времени не должны были выдаваться подлинники особо ценных документов, на которые был изготовлен фонд пользования. Однако в 1990е гг. из-за плохой обеспеченности позитивной пленкой началось отставание изготовления микрофильмов фонда пользования от микрофильмов страхового фонда, а с 1995 г. работы по изготовлению фонда пользования прекратились. Всего за 1992-1994 гг. было изготовлено 315176 кадров фонда пользования [6, с. 110].

Отбор документов на реставрацию проводился с учетом ценности заключенной в них информации и степени их использования. В 1991-1994 гг. годовые объемные показатели по физической реставрации документов составляли в среднем 29 тысяч листов. С 1995 г. объемные показатели начали неуклонно снижаться. Если в 1995 г. годовой объем реставрационных работ составлял 25200 листов, в 1996-1997 гг. в среднем - 14 тысяч листов, то, начиная с 1999 г., он снизился до 7 тысяч листов. С 1991 г. ЦГА ЧР освоил реставрацию крупноформатных документов (картографического материала), которая продолжалась вплоть до 1994 г. Была проведена работа по реставрации 925 карт и газетного материала в количестве 200 л [2, д. 808, л. 48]. Из-за отсутствия средств на приобретение расходных материалов работы были прекращены.

На все фонды ЦГА ЧР имелся полный комплекс учетных документов: листы фондов, карточки фондов, дела фондов, описи дел, список фондов. Кроме основных учетных документов велись вспомогательные: журнал учета ежедневного движения дел в целом по госархиву и по архивохранилищам; журнал учета свободных номеров фондов; журнал учета движения описей; алфавитный указатель к листам фондов.

В архивохранилищах велись списки фондов, карточки пофондового и постеллажного указателей, физического состояния документов; учета документов, имевших во внешнем оформлении или в приложении к ним материальные ценности. Были составлены и оформлены паспорта архивохранилищ. Централизованный учет документов в госархивах до 2001 г. осуществляли главные хранители.

Однако только у 566 фондов были описи в трех экземплярах (8,18\%). Некомплектность описей имели фонды дореволюционного периода, а также поступившие на хранение в 1920-1930-е гг. На 01 января 2005 г. в этом направлении были достигнуты значительные изменения: 22,21 \% описей соответствовало требованиям по экземплярности. Таким образом, целенаправленный характер в рассматриваемый период приобрел процесс усовершенствования и переработки описей. В ЦГА ЧР этому способствовала организация в 1987 г. отдела научно-справочного аппарата. При усовершенствовании описей особое внимание уделялось созданию указателей [2, д. 1020, л. 97].

В 1991-2004 гг. в деятельности архива одним из самых ответственных и трудоемких направлений стала работа по исполнению запросов социально-правового характера. Как отмечала заместитель директора ЦГА ЧР Е.П. Дроздовская, в 1980-е гг. количество запросов социально-правового характера не превышало 100 в год, на их исполнении находился один человек [10, с. 38]. В 1990-е гг. в связи с изменениями в общественно-политической жизни страны, принятием Президентом Российской Федерации и Правительством Российской Федерации новых нормативных правовых документов по пенсионному законодательству, обеспечению социальных прав граждан, пересмотром ранее действовавших и установлением новых дополнительных льгот отдельным категориям граждан, количество поступавших в архивные учреждения запросов резко возросло.

Наибольшее количество, около 50\% поступивших запросов и выданных архивом справок, пришлось на 1991-1993 гг. В течение 1993 г. приказами директора ЦГА чР создавались четыре дополнительные рабочие группы общим количеством 32 человека по работе с заявлениями социально-правового характера [2, д. 824, л. 82]. Анализ производственной деятельности и эффективности использования штатной численности, который периодически проводился архивом, также показывал, 
что в связи с первоочередным исполнением запросов граждан, плановые показатели некоторых видов работ не выполнялись [2, д. 904, л. 30].

В 1996 г. в ЦГА ЧР ситуация с исполнением запросов граждан резко обострилась. Срок исполнения запросов увеличился в этот период до шести месяцев. Тем не менее, архивисты делали все от них зависящее. Подтверждением приоритетности данного направления свидетельствует то, что 50 \% бюджета рабочего времени по ЦГА ЧР затрачивалось на использование и публикацию документов [2, д. 904, л. 31].

С 1988 г. началась работа по рассекречиванию документов. Однако фактически вплоть до 1992 г. этим занимался только один сотрудник. По состоянию на 01 января 1987 г. в госархиве на секретном хранении значилось 37339 дел. В период с 1988 по 1991 гг. с участием представителей организаций-фондообразователей было рассекречено и передано на общее хранение 18625 ед. хр. по 39 фондам, в т.ч. 956 ед. хр. досоветского периода. Таким образом, засекреченных документов досоветского периода не осталось. В результате проведенной работы в научный оборот были введены документы личных дел служащих уездных полицейских управлений, тюремных надзирателей, алфавитные книги заключенных, сводки о количестве и движении заключенных, переписка о борьбе с дезертирством, личные дела австро-германских поданных [2, д. 867, л. 137-138]. Тем не менее, к большей части рассекреченных в этот период документов (90,3%) допуск был ограничен - это личные дела раскулаченных, документы прокуратуры, завода № 320 и т.д.

С 1992 г. работа стала носить целенаправленный характер. За каждым членом комиссии были закреплены фонды, имевшие документы с секретным грифом. Ежегодно составлялся план-график работы комиссии. Всего за период с 1991 по 2004 гг. комиссией по рассекречиванию документов ЦГА ЧР было проведено около 130 заседаний, на которых рассматривались вопросы возможности передачи документов с секретного на общее хранение, порядок использования этих документов, методические аспекты проводимой работы. С привлечением представителей организаций рассекречивались фонды Министерства сельского хозяйства ЧАССР, Завода № 320, Отдела мест заключения МВД Чувашской АССР, Алатырского детского приемника-распределителя, Отдела пожарной охраны и др. Некоторые учреждения, такие как Госбанк и Военкомат Чувашской Республики, делегировали полномочия по рассекречиванию документов своих фондов госархиву [9, с. 167].

1990-е годы характеризовались расширением выставочной деятельности в госархиве, как совместной с другими архивами республики, так и с Национальным музеем, министерствами, ведомствами. Всего за эти годы было подготовлено 30 выставок документов. Так, сотрудники госархива активно участвовали в создании выставок к ежегодно отмечаемому с 1995 г. Дню чувашской государственности. Было подготовлено также 5 выставок посвященных Великой Отечественной войне («Шла война народная» - к 50-летию начала Великой Отечественной войны - «Детство, опаленное войной», «Всенародная помощь фронту», «Подвиг Ваш бессмертен», «Мы были, есть и будем»). Готовились выставки, экспонировавшиеся в рамках мероприятий, посвященных юбилейным датам выдающихся земляков, районов, городов, памятным событиям. В 2000 г. госархив принимал участие в выявлении документов для экспозиции открытого в г. Чебоксары Музея воинской славы Чувашской Республики. Часть предоставленных Музею копий документов была представлена в его экспозиции.

Несмотря на значительные трудности в финансировании подготовки и издания документальных публикаций, возникшие в 1990-е гг. в связи с переходом к рыночным отношениям, архивные учреждения республики не снизили по сравнению с предшествующим десятилетием число подготовленных к изданию трудов, сборников документов, летописей, сборников статей, буклетов и др. Это связано, прежде всего, с возрастанием интереса к истории родного края, района, села, расширением использования архивной информации.

Сотрудниками госархива было создано 3 сборника документов научно-популярного типа: «Страницы немеркнущей славы. Уроженцы Чувашии на фронтах Великой Отечественной войны 1941-1945 гг. Письма, дневники и воспоминания, статьи и выступления по радио, фотографии» (1995 г.), «Дороги Чувашии. От бездорожья до современных автодорог. Документы и материалы, воспоминания и статьи, фотографии о дорожном строительстве в Чувашии (1920-1997 гг.)» (1998 г.), «Потребительская кооперация Чувашии в 1920-2000 гг. Документы, материалы, воспоминания, статьи и фотографии» (2000 г.) [2, д. 922, л. 48]. Приоритетным направлением в тематике стала история народного хозяйства Чувашской Республики.

Совместно с Чувашским государственным гуманитарным институтом, Чебоксарским художественным училищем, Чувашским государственным университетом им. И.Н. Ульянова были изданы сборники статей, путеводители из серии «Памятные места Чебоксар»: «Древний центр города - Западный косогор», «Владимирская горка и Коммунальная Слобода» [4, с. 9].

В 1991-2000 гг. расширилось сотрудничество архивных учреждений со средствами массовой информации. По сравнению с предшествующим десятилетием на- 
блюдался рост количества материалов, подготовленных для них. Повысилась содержательность, расширилась тематика подготовленных материалов. В рамках использования архивных документов в средствах массовой информации госархивом в этот период было подготовлено 70 самостоятельных радиопередач. Основными темами стали: Великая Отечественная война, Первая мировая война, известные военачальники - уроженцы Чувашии, голод в Поволжье 1921-1922 гг., история Чувашрадио, работа промысловых артелей, женское движение, архивное строительство в Чувашии, дорожное строительство, культура, образование [2, д. 922, л. 46-47].

Все, чего удалось добиться в республике по сохранению, приумножению и использованию архивов, было сделано усилиями конкретных людей. В непростые 1990е гг. продолжалась активная работа сотрудников ЦГА ЧР по созданию страхового фонда и фонда пользования на особо ценные документы архива. Благодаря деятельности Л.А. Данилова, В.М. Корейкина, Л.И. Кирилловой удалось сохранить богатейший материал, в т.ч. аудиовизуальные и фотодокументы.

Большую работу в области разностороннего использования колоссального информационного потенциала Архивного фонда Чувашской Республики проделали А.П.
Петров, В.Ф. Питернова, С.И. Выйкин, Е.А. Гальперина и многие другие. Радиопередачи, видеосюжеты, сборники документов, подготовленные архивистами Чувашии, были высоко оценены на федеральном и республиканском уровнях [3].

Таким образом, в непростых условиях реформ 1990х гг. ЦГА ЧР удалось сделать колоссальный шаг вперед. Было налажено выявление и учет особо ценных и уникальных документов, продолжалось создание страхового фонда, фонда пользования, консервационно-профилактическая обработка документов и др. Архивистам удалось не только обратить внимание на необходимость решения этих проблем, но организовать целенаправленную деятельность в этом направлении. Продолжалась активная деятельность по созданию и совершенствованию научно-справочного аппарата. Расширились формы использования архивных документов. Так, Интернет-выставки стали удачным сочетанием сведений о прошлом нашей республики и передовых информационных технологий. Все чаще стали обращаться в архив не только ученые, краеведы, но и граждане, интересующиеся своей родословной и вообще отечественной историей. Наблюдалась тенденция неуклонного роста интереса общества к информации, основанной на архивных документах.

\section{ЛИТЕРАТУРА}

1. Государственный исторический архив Чувашской Республики. Ф. Р-819. «Управление по делам архивов Министерства культуры, по делам национальностей, информационной политики и архивного дела Чувашской Республики». Оп. 8.

2. Государственный исторический архив Чувашской Республики. Ф. Р-2315 «Государственный исторический архив Чувашской Республики». Оп. 1.

3. Архивное дело Чувашской Республики в лицах (справочник). - Чебоксары. 2004. 220 с.

4. Выйкин А.В. Архивы Чувашии на рубеже веков. // Материалы научно-практической конференции «Архивы Чувашии в XXI веке: опыт, проблемы и перспективы развития». - Чебоксары: Госкомархив Чувашии. 2001. С. 5-15.

5. Кузнецов А.К. Государственная архивная служба Чувашской Республики в 1991-2004 годах: некоторые итоги деятельности // Исторический вестник (Чебоксары). 2012. № 1 (1). С. 18-35.

6. Кузнецов А.К. Обеспечение сохранности архивных документов в 1990-х годах (на примере Центрального государственного архива Чувашской Республики) // Вестник Чувашского университета. 2009. № 3. С. 106-111.

7. Кузнецов А.К. Сеть государственных архивов Чувашской Республики в начале 1990-х гг. // Вестник Чувашского университета. 2008. № 4. С. 57-61.

8. Кузнецов А.К. Работа с особо ценными документами в Центральном государственном архиве Чувашской Республики в 1990-е гг. // Актуальные проблемы истории России XX века. Материалы региональной научно-практической конференции. 2008. С. 144-148.

9. Кузнецов А.К. Рассекречивание документов в Центральном государственном архиве Чувашской Республики в 1990-е гг. // Проблемы исторической регионалистики. Сборник научных статей. 2009. С. 165-170.

10. Сокровищница документальной памяти. Центральному государственному архиву Чувашской Республики - 60 лет. - Чебоксары: Госкомархив Чувашии. 2001.62 c.

(c) Кузнецов Антон Константинович (kuznetsov-ak@mail.ru).

Журнал «Современная наука: актуальные проблемы теории и практики» 